Contents list available at IJRED website

Int. Journal of Renewable Energy Development (IJRED)

Journal homepage: https: / /ijred.undip.ac.id

\title{
Lignocellulosic Bioethanol Production of Napier Grass Using Trichoderma reesei and Saccharomyces cerevisiae Co-Culture Fermentation
}

\author{
Thirawat Mueansichaia , Thaneeya Rangseesuriyachai ${ }^{b, *}$, Nuttha Thongchulc,d, \\ Suttichai Assabumrungrate \\ ${ }^{a}$ Department of Chemical and Materials Engineering, Faculty of Engineering, Rajamangala University of Technology Thanyaburi, \\ Pathumthani 12110, Thailand \\ ${ }^{b}$ Department of Civil Engineering, Faculty of Engineering, Rajamangala University of Technology Thanyaburi, Pathumthani 12110, \\ Thailand \\ ${ }^{c}$ Institute of Biotechnology and Genetic Engineering, Chulalongkorn University, Bangkok 10330, Thailand \\ ${ }^{d}$ Research Unit in Bioconversion/Bioseparation for Value-Added Chemical Production, Institute of Biotechnology and Genetic
} Engineering, Chulalongkorn University, Bangkok 10330, Thailand

e Department of Chemical Engineering, Faculty of Engineering, Chulalongkorn University, Bangkok 10330, Thailand

\begin{abstract}
Bioethanol from agricultural waste is an attractive way to turn waste into added value that will solve the problem of food competition and waste management. Napier grass is a highly productive and effective lignocellulosic biomass, which is an important substrate of the second-generation biofuels. In addition, several processes are required in the production of ethanol from lignocellulosic materials; thus, co-culture fermentation can shorten the production process. This experimental research utilizes Trichoderma reesei and Saccharomyces cerevisiae co-culture fermentation in the bioethanol production of Napier grass using simultaneous saccharification and fermentation technology. To improve ethanol yield, Napier grass was pretreated with $3 \%(\mathrm{w} / \mathrm{w})$ sodium hydroxide. An orthogonal experimental design was employed to optimize the Napier grass content, mixed crude co-culture loading, and incubation time for maximum bioethanol production. The results showed that pretreatment increased cellulose contents from $52.85 \%$ to $82 \%$. The optimal fermentation condition was $15 \mathrm{~g}$ Napier grass, $15 \mathrm{~g}$ mixed crude co-culture, and 7 days incubation time, which maximizes the bioethanol yield of $16.90 \mathrm{~g} / \mathrm{L}$. Furthermore, the fermentation was upscaled 20 -fold, and experiments were performed with and without supplemented sugar using laboratory-scale optimal fermentation conditions. The novelty of this research lies in the use of a mixed crude co-culture of T. reesei and S. cerevisiae to produce bioethanol from Napier grass with the maximum bioethanol concentration of $25.02 \mathrm{and} 33.24 \mathrm{~g} / \mathrm{L}$ under unadded and added sugar conditions and to reduce operational step and capital costs.
\end{abstract}

Keywords: Bioethanol; Napier grass; Trichoderma reesei; Saccharomyces cerevisiae

Article history: Received: 20th Nov 2021; Revised: $9^{\text {th }}$ Jan 2022; Accepted: $16^{\text {th }}$ Jan 2022; Available online: $25^{\text {th }}$ January 2022 How to cite this article: Mueansichai, T., Rangseesuriyachai, T., Thongchul, N., and Assabumrungrat, S. (2022) Lignocellulosic Bioethanol Production of Napier Grass Using Trichoderma reesei and Saccharomyces cerevisiae Co-Culture Fermentation. Int. J. Renew. En. Dev., 11(2), 423433

https://doi.org/10.14710/ijred.2022.43740

\section{Introduction}

The Sustainable Development Goals (SDGs) are the world's shared plan to achieve a better and more sustainable future quality of life. Affordable and clean energy is one of the 17 goals for sustainable community development. In addition, the use of clean energy can also achieve the climate action goal to solve the current climate change problem, which is another goal of SDG. Bioethanol is renewable energy made from biomass or agricultural byproducts, resulting in a clean emission during combustion. Thailand is abundant in energy plants, including grasses, which can be excellent feedstocks for a variety of highvalue products, including bioethanol. Unlike the firstgeneration ethanol that relies on sugar crops, the secondgeneration bioethanol utilizes lignocellulosic materials (energy plants) and agricultural wastes to mitigate food insecurity (Restiawaty et al., 2020; Sudiyani et al., 2016; Menegol et al., 2016; Sanford et al., 2017).

Napier grass (Pennisetum purpureum) typically grown as animal feed, is considered a lignocellulose material, which has a long lifespan with high crop yields and yearround harvest. It has been known as an energy plant and is a promising alternative for bioethanol production

* Corresponding author: thaneeya.r@en.rmutt.ac.th 
because of high crop productivity, ubiquity, abundance, and diverse applications. Napier grass has high nutritional benefits containing $30.9 \%$ carbohydrates, $27 \%$ proteins, $14.8 \%$ lipids, $18.2 \%$ total ash, and $9.1 \%$ fiber (as dry weight) (Sawasdee \& Pisutpaisal, 2014). Napier grass is a high-carbohydrate biomass known to be a precursor to ethanol conversion. Moreover, this plant contains approximately $\quad 45 \%-50 \%$ of cellulose, $\quad 30 \%-32 \%$ hemicellulose, and 18\%-22\% lignin (Kommula et al., 2013; Reddy et al., 2014). Previous studies have used Napier grass as raw material to produce bioethanol through a variety of processes, enzymes, and pretreatment methods. Kongkeitkajorn et al. (2020) evaluated the ethanol production potential from Napier grass with the different pretreatment methods and ethanol production processes by using Saccharomyces cerevisiae and Scheffersomyces shehatae, a xylose-fermenting yeast. They found that alkaline pretreatment with sodium hydroxide $(\mathrm{NaOH})$ using separate hydrolysis and fermentation (SHF) processes showed the best condition with high ethanol yields (44.7 g/L). Tsai et al. (2018) reported that Napier grass could be converted to ethanol production of $0.143 \mathrm{~g} / \mathrm{g}$ raw material by applying simultaneous saccharification and fermentation (SSF) with dried yeast (S. cerevisiae) and cellulase (CTec2) after pretreatment with an alkaline solution.

Bioethanol production involves two main processes: hydrolysis and fermentation. There are many methods for hydrolysis: enzymatic, acid, and base hydrolysis (Kusmiyati et al., 2016; Adekunle et al., 2016). In conventional SHF, hydrolysis is initially performed to convert cellulose into sugars for subsequent fermentation. However, SHF suffers from multiple operational units and relatively high energy consumption (Alfani et al., 2000; Cotana et al., 2015). On the other hand, SSF integrates hydrolysis and fermentation into one single operational unit. The advantages of SSF are relatively low investment and operational costs (Wingren et al., 2003). As reported by previous literatures (Dahnum et al., 2015; Xu et al., 2015), SSF is superior to SHF because of higher ethanol production efficiency. The superior performance is attributable to lower glucanase and cellobiohydrolase in SSF than in SHF (Banka et al., 2015; Loaces et al., 2017). Burman et al. (2019) found that acid mine drainage pretreatment achieved a final ethanol concentration of $14.43 \mathrm{~g} / \mathrm{L}$ for $\mathrm{SHF}$ and $14.83 \mathrm{~g} / \mathrm{L}$ for SSF.

Enzymes play an important role in the bioethanol production of lignocellulose materials, including grass. Specifically, fungi are responsible for converting cellulose into monosaccharides during hydrolysis. In practice, fermentation using whole cells of microorganisms is cheaper than using commercial enzymes. Commonly used cellulolytic fungi are mutant strains of Trichoderma reesei (Gusakov et al., 2011). Meanwhile, yeast converts sugars into ethanol during fermentation (Ariyanti and Hadiyanto, 2013). Common yeast strains for bioethanol production include S. cerevisiae, Scheffersomyces stipitis, and Schizosaccharomyces pombe (Azhar, et al., 2017). In addition, Siwarasak et al. (2012) utilized the co-culture of $T$. reesei and $S$. cerevisiae in the SSF process for ethanol production of various sugar crops. Meanwhile, Escherichia coli and $S$. cerevisiae were the example of the co-culture system used in the bioethanol production of Napier grass (Yasuda et al., 2014), T. reesei, Aspergillus niger and Zymomonas mobilis (Liu et al., 2017), S. cerevisiae and
Pichia stipites (Wongwatanapaiboon et al., 2012), Bacillus sp. and Klebsiella oxytoca (Tran et al., 2013), and Aspergillus niger and S. cerevisiae (Eliana et al., 2014). However, there is less data on the use of $T$. reesei and $S$. cerevisiae mixed-strain fermentation in the bioethanol production of Napier grass. As mentioned above, there are various influential factors in identifying the independent variable for the potential of ethanol production. The number of trials to cover all factors needs to be large. The optimization of important parameters such as substrate, enzyme, and interaction time duration should be taken into account. An effective statistical model based on experimental design is necessary to use for analyzing the variable amount and the effect of the interaction parameters on ethanol yields. Orthogonal array design is one of the factorial designs of experiment (DOE) methods, which deals with minimum numbers of experiments and optimizes the parameters in the ethanol process at a time by using the orthogonal design table and statistical analysis (Akhtar et al., 2017). Moreover, orthogonal design data can be used to consider for scaling up to increase interest in the industrial application. Sharma et al. (2019) reported the utilization of the Taguchi orthogonal array design, kinetics, and modeling to scale up and optimize ethanol production from freshwater algae, Rhizoclonium $s p$. of Trans Himalayas. Sharma et al. (2020) stated that the simulation software and life cycle assessment show that second-generation bioethanol production will reduce the environmental impact and it is the regeneration of the bioresource. The novelty of this research lies in the use of the mixed crude co-culture of $T$. reesei and $S$. cerevisiae to produce bioethanol from Napier grass and to reduce operational and capital cost.

This research thus investigates the application of a coculture of $T$. reesei and $S$. cerevisiae in the ethanol fermentation of Napier grass using SSF. Prior to SSF, Napier grass was pretreated with $3 \%(\mathrm{w} / \mathrm{w}) \mathrm{NaOH}$. The fermentation parameters under study were Napier grass content, mixed crude co-culture loading, and incubation time; orthogonal experimental design was used to optimize the parameters for maximum bioethanol yield. Furthermore, fermentation was upscaled 20-fold, and experiments were carried out under unadded and added sugar. This study will improve the potential of bioethanol production by using $\mathrm{NaOH}$ pretreatment and $\mathrm{SHF}$ processes generally used in industries. It will help to reduce the cost of ethanol production through the shorter production time and easier enzyme production as well as the utilization of waste that can be used to produce ethanol. The emergence of agriculture has created the possibility of zero waste management.

\section{Materials and methods}

\subsection{Preparation of materials}

In this research, Napier grass was acquired from a plantation in Thailand's central province of Suphan Buri. The grass was chopped into smaller pieces of $1-3 \mathrm{~cm}$ in length and oven-dried at $80^{\circ} \mathrm{C}$ until the moisture content was below $10 \%$. The dried grass was ground and sieved using sieve No. 100 prior to pretreatment with $3.0 \%$ (w/w) $\mathrm{NaOH}$ 


\section{2 $\mathrm{NaOH}$ pretreatment}

Alkaline pretreatment was carried out by immersing $10 \%(\mathrm{w} / \mathrm{v})$ of dried Napier grass powder in $3.0 \%(\mathrm{w} / \mathrm{w})$ $\mathrm{NaOH}$ solution in an Erlenmeyer flask (Pensri, et al., 2016). The slurry was processed in the autoclave at $121 \square \mathrm{C}$ (15 psi) for $60 \mathrm{~min}$ and left to cool to room temperature. The solid was then filtrated, washed by tap water to neutralize $\mathrm{pH}$, and oven-dried at $103^{\circ} \mathrm{C}$ for $60 \mathrm{~min}$. Both pre- and post-treated Napier grass powder were analyzed and compared for cellulose, hemicellulose, and lignin. The compositional analysis was carried using the Technical Association of Pulp and Paper Industry (TAPPI) standard: TAPPI T203 om-88 test method for cellulose and hemicellulose contents and TAPPI T222 om-88 test method for lignin content.

\subsection{Co-culture fermentation preparation}

Mixed crude co-culture of $T$. reesei and $S$. cerevisiae (1:1) was utilized to enhance ethanol production. According to (Prajankate, 2011), co-culture contributed to enhanced ethanol yields compared with utilization of one strain. The mixed crude co-culture fermentation was cultured by co-culturing microorganisms in the same potato dextrose agar plate at $25^{\circ} \mathrm{C}$ for 7 days. Afterward, solid-state cultivation was performed at $\mathrm{pH} 5$ in raw dried tapioca chips $(5-15 \mathrm{~mm})$ and incubated at $24^{\circ} \mathrm{C} \pm 2^{\circ} \mathrm{C}$ for 5 days for mixed crude enzyme powder. Samples were collected on a daily basis to determine microorganism concentration and reducing sugar.

\subsection{DOE}

An orthogonal experimental design was utilized to optimize three independent variables (x1, x2, and $\mathrm{x} 3$ ), under seven different levels for an optimal fermentation condition with maximum ethanol yield, where $\mathrm{x} 1, \mathrm{x} 2$, and x3 are respectively Napier grass powder content, mixed crude co-culture loading, and incubation time. Table 1 tabulates L49 (73) orthogonal design with Napier grass powder content (g), mixed crude co-culture loading (g), and incubation time (d) under seven experimental levels. The experiments were performed in duplicate. The ethanol concentration $(\mathrm{g} / \mathrm{L})$ was considered as response values to analyze the influential order of the amounts of substrate and mixed crude enzyme and incubation time to optimize the conditions. Statistical analysis was conducted using standard statistical software (SPSS version 22). A value of $p<0.05$ was regarded as statistically significant. Moreover, the data was reported using mean \pm standard deviation.

Statistical analysis of orthogonal experiments for ethanol yields were calculated based on two important parameters of $k_{a b}$ and $K_{a b}$. $K_{a b}$ equals to the sum amount of ethanol productivity at all levels $(\mathrm{a}=$ level 1-7 in Table 1 ) in each factor $(b=A, B$, and $C$ in Table 1$) . k_{a b}$ is the average of $K_{a b}$ in each level (a) of factor (b).

\subsection{Bioethanol fermentation}

Laboratory-scale SSF for Napier grass-based ethanol was carried out under the optimal condition from the orthogonal array design. The liquid media (LM) was first

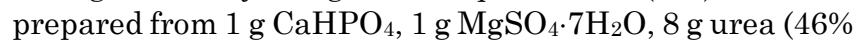
$\left.\left(\mathrm{NH}_{4}\right)_{2} \mathrm{SO}_{4}\right), 15 \mathrm{~g}$ phosphate (NPK-0-52-34), and $1000 \mathrm{~mL}$ pure water at $\mathrm{pH} 5$ and stirred for $30 \mathrm{~min}$. Dried Napier grass powder already treated with $\mathrm{NaOH}$ solution as mentioned in section 2.2 and $\mathrm{LM}$ were autoclaved at $121^{\circ} \mathrm{C}$ for 15 min. Then, sterilized Napier grass and mixed crude co-culture with various contents indicated in Table 1 were introduced into the 500-mL Erlenmeyer flask with $300-\mathrm{mL}$ sterilized LM mixture. The flasks were capped with cotton wool and shaken at $100 \mathrm{rpm}$ and $30^{\circ} \mathrm{C}$ until termination following the design incubation time (Table 1). The laboratory-scale schematic diagram of orthogonal experiments used in the study is shown in Figure 1. Samples were collected on a daily basis, and cell mass, reducing sugar, and ethanol yield were determined.

Table 1

Design of orthogonal experiment under study

\begin{tabular}{cccc} 
& \multicolumn{3}{c}{ Factors } \\
\cline { 2 - 4 } Level & A & B & C \\
\cline { 2 - 4 } & Napier grass (g) & Mixed crude co-culture & Incubation time (d) \\
\hline 1 & 5 & $(\mathrm{~g})$ & 3 \\
2 & 10 & 2.5 & 4 \\
3 & 15 & 5 & 5 \\
4 & 20 & 7.5 & 6 \\
6 & 25 & 10 & 7 \\
7 & 30 & 12.5 & 8 \\
\hline
\end{tabular}




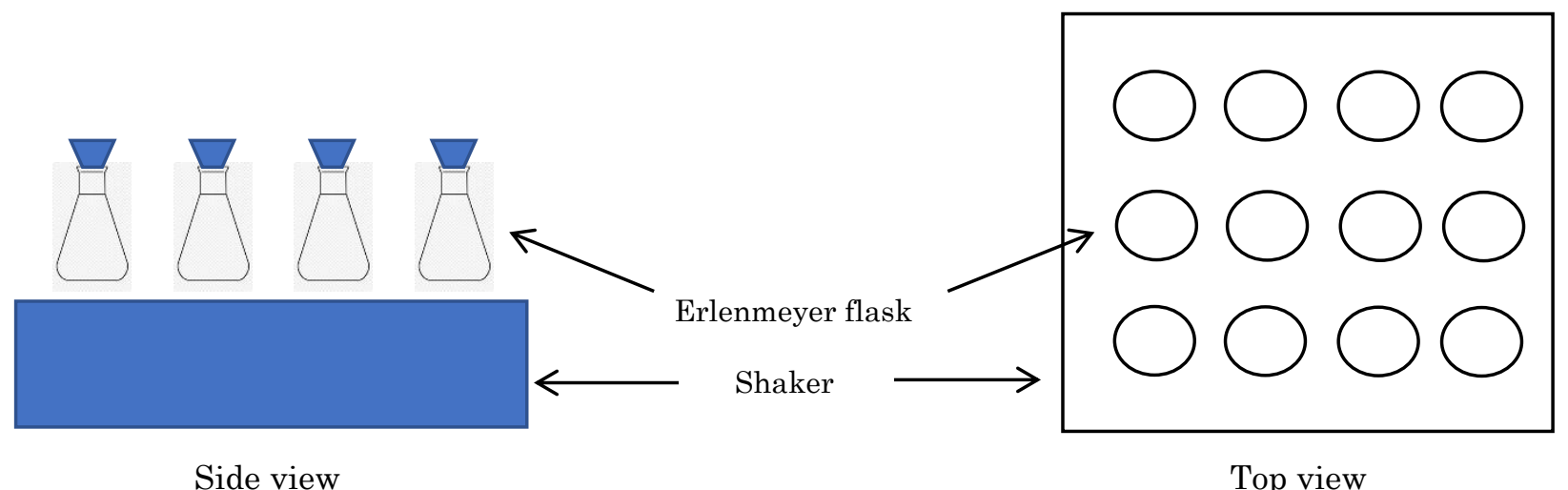

Fig 1 The laboratory-scale schematic diagram of orthogonal experiments for simultaneous saccharification fermentation (SSF) for Napier grass

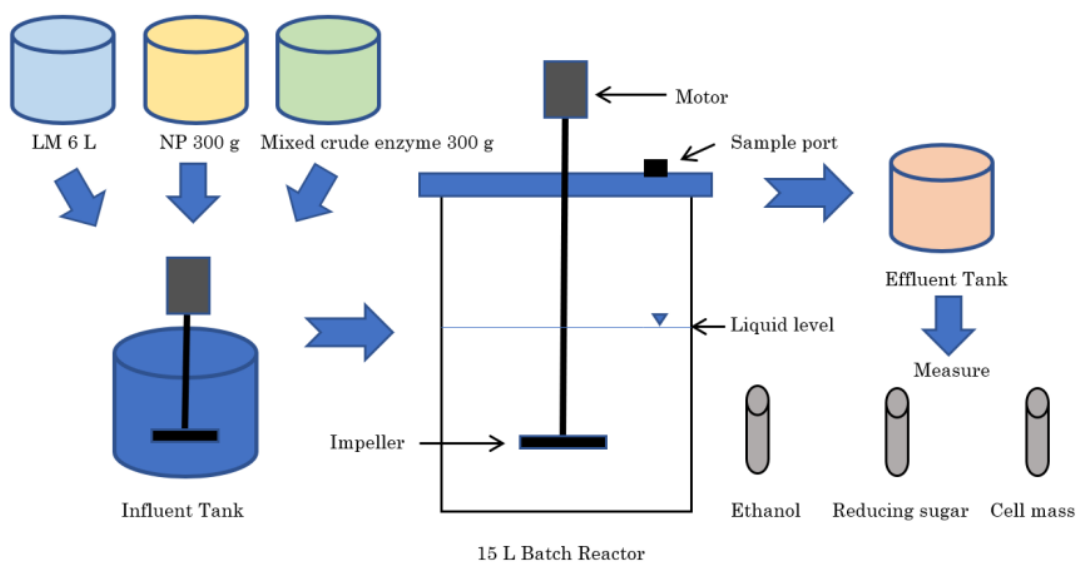

Fig 2 The scale-up schematic diagram of batch reactor for simultaneous saccharification fermentation (SSF) for Napier grass

To scale up, the fermentation was enlarged 20 -fold by using the ratio with the highest total concentration of ethanol from the orthogonal fermentation method in Table 1. The highest amount of ethanol when using $15 \mathrm{~g}$ of $\mathrm{NP}$ and $15 \mathrm{~g}$ of mixed crude co-culture when the aforementioned results were enlarged to 20 times. The amount of grass used in fermentation and mixed microbial powder was $300 \mathrm{~g}$. LM (without sugar) to be added to the 20 -fold expansion fermentation was $6 \mathrm{~L}$ in a 15 - $\mathrm{L}$ reactor using impellers (Figure 2). Sterilization and then mix all materials with as in laboratory-scale experiments at $\mathrm{pH} 5$. The fermentation was carried out under anaerobic conditions at $100 \mathrm{rpm}$ for $3 \mathrm{~h}$. The batch-scale fermentation was performed under the optimal condition from the orthogonal design experiments (the best condition of the amounts of Napier grass (150 g), mixed crude enzyme (150 g), and incubation time (7 days)) with different experimental settings, with and without added sugar, and the ethanol yields were compared. The theoretical bioethanol yields were calculated using the equation (1) based on the maximum (51\%) (\%conversion of glucose into ethanol by yeast).

The ethanol yield $(\%)=\frac{\text { Ethanol produced }(\mathrm{g})}{\text { Initial sugar }(\mathrm{g}) \times 0.511} \times 100$
Sugar was added more to provide energy for the microorganisms and to see the effect of adding sugar on increased ethanol yield. This is because sugar is typically added in the ethanol production process to provide microorganisms with a sufficient energy source. Finally, samples were collected on a daily basis to determine cell mass, reducing sugar, and ethanol yield.

\subsection{Analytical methods for this study}

The microorganism concentration (cell mass) was prepared in pure water suspension and determined using a hemacytometer (Boeco, Germany) with a 40x microscope. Reducing sugar concentrations were estimated with 3,5dinitrosalicylic acid reagent (Miller, 1959). The ethanol concentrations were determined using the dichromate colorimetric method (Williams \& Reese, 1950)

\section{Results and Discussion}

\subsection{The effect of alkaline pretreatment}

Napier grass contains essential nutrients, i.e., carbon $(48.60 \% 0 \pm .80 \%)$, hydrogen $(6.01 \pm 0.14)$, sulfur $(0.32 \pm$ $0.01)$, and nitrogen $(0.99 \% \pm 0.33 \%)$ for microorganism growth and the structural composition with cellulose $(38.8 \% \pm 2.30 \%)$, hemicellulose $(19.80 \% \pm 1.68 \%)$, lignin $(27.00 \% \pm 1.29 \%)$, and extractives $(12.07 \% \pm 0.32 \%)$ 
(Mohammad et al. 2015). Cellulose is dominant in plant cell walls, which is enzymatically converted into monosaccharides for bioethanol production (Rahayu et al., 2017). Hemicellulose and lignin, however, hinder enzymes from breaking down cellulose into glucose during fermentation (Chaturvedi \& Verma, 2013). Before Napier grass is used as the carbon substrate in ethanol fermentation, pretreatment is required to remove lignin and hemicellulose, thereby improving digestion and subsequent fermentation efficiency (Eliana et al., 2014).

Figure 3 illustrates the chemical composition of dried Napier grass powder before $3 \%(\mathrm{w} / \mathrm{w}) \mathrm{NaOH}$ pretreatment, consistent with the previous report (Pensri et al., 2016; He et al., 2017). Figure 1 also depicts the compositional properties of dried Napier grass powder after $\mathrm{NaOH}$ pretreatment, indicating changes in the composition of lignocellulosic biomass as lignin was removed and hemicellulose was transformed into cellulose. The chemical compositions of native and pretreated Napier grass were averaged at $9.2 \% \pm 0.56 \%$ and $3.6 \% \pm 0.63 \%$ for lignin, $52 . \pm \% 851.12 \%$ and $82.45 \% \pm 0.78 \%$ for cellulose, and $18.2 \% \pm 0.32 \%$ and $8.6 \% \pm 0.85 \%$ for hemicellulose. Native Napier grass has significantly different chemical composition changes after pretreatment $(p<0.05) . \mathrm{NaOH}$ pretreatment can improve native Napier grass as a proper material for bioethanol production by increasing $29.6 \%$ of cellulose and removing $5.6 \%$ of lignin and $9.6 \%$ of hemicellulose. The compositional properties of native Napier grass include cellulose, hemicellulose, lignin, and others (ash, lipids, sugars, and proteins) (Triantafyllidis et al., 2013). According to (Lui et al. 2017), Napier grass consists of cellulose $(40 \%-50 \%)$, hemicellulose $(25 \%-35 \%)$, and lignin $(15 \%-25 \%)$. High cellulose contents of Napier grass render the plant ideal for bioethanol production. According to (Taherzadeh, 2008; Kim et al., 2016; Chen et al., 2017), complex lignin structures hinder chemical and biological degradation, thereby lowering ethanol fermentation efficiency. According to Kamarullah, (2015), hemicellulose is mainly composed of fermentationresistant pentose. Moreover, pretreatment also improved sugar conversion during hydrolysis (Mafuleka \& Kana, 2015). As mentioned in the literature, other components such as proteins, lipids, and ash strongly affect bioethanol yield (Cotana et al., 2015; Burman et al., 2020). The pretreatment step becomes an important step to minimize the composition of the other components. The yield of bioethanol depends on the amount of glucose from raw material.

\subsection{Microorganism plate count}

Table 2 tabulates the plate counts of microorganisms in the mixed crude co-culture of $T$. reese $i$ and $S$. cerevisiae, consisting of $<10 \mathrm{CFU} / \mathrm{g}$ total bacteria, $<10 \mathrm{CFU} / \mathrm{g}$ total yeast, and $2.67 \times 10^{8} \mathrm{CFU} / \mathrm{g}$ total fungi. The results revealed that yeast counts (S. cerevisiae) were considerably less than that of fungi (T. reesei), but the number of microorganisms in the co-culture is enough for fermentation. According to Azhar et al. (2017), yeast strains such as $S$. cerevisiae minimally grow on substrate due to their inability to compete with other wild-type yeasts and fungi. The mixed crude co-culture is durable and able to convert sugars into ethanol

\subsection{Laboratory-scale ethanol fermentation using mixed crude co-culture}

The optimal Napier grass content, mixed crude coculture loading, and incubation time that maximizes the bioethanol yield $(16.90 \mathrm{~g} / \mathrm{L})$ were $15 \mathrm{~g}, 15 \mathrm{~g}$, and 7 days, respectively (Table 3 ). In Table $4,15 \mathrm{~g}$ of mixed crude coculture, $15 \mathrm{~g}$ of Napier grass, and 7 days incubation time were chosen to be the optimal level for each factor $\left(\mathrm{B}_{6} \mathrm{~A}_{3} \mathrm{C}_{5}\right)$. The major-minor order was considered from a larger $\mathrm{R}$ that indicates the effect sequence on the results of ethanol yields. The influence factors from main to secondary were as follows: amount of mixed crude co-culture enzyme $>$ amount of Napier grass > incubation time. In other words, the optimal Napier grass-to-co-culture ratio was 1:1, given the 7-day incubation time. The optimal fermentation condition was further validated in batch-scale experiments using 15-L bioreactor tanks (6-L working volume) in two experimental settings: with and without added sugar. The pilot-scale experiments were performed to collect data from $300 \mathrm{~g}$ of mixed crude co-culture and $300 \mathrm{~g}$ of Napier grass. Then, the ethanol production of both conditions (with and without added sugar) was collected daily until 7 days was completed (optimum incubation time), and the data collection was extended until the $9^{\text {th }}$ day to determine the trend of ethanol production.

\subsection{Batch-scale ethanol fermentation using mixed crude co-culture}

The optimal condition to scale up was obtained from the orthogonal experiments of the DOE in Table 4. The optimal ethanol production was obtained under optimal conditions by a 20 -fold scale up from the optimization scheme $\left(\mathrm{B}_{6} \mathrm{~A}_{3} \mathrm{C}_{5}: 15 \mathrm{~g}\right.$ mixed crude co-culture, $15 \mathrm{~g}$ Napier grass, and 7 days incubation time). To imitate commercial-scale production, the batch-scale experiments using 15-L bioreactor tanks were carried out under the optimal SSF fermentation condition: $15 \mathrm{~g}$ Napier grass, 15 g mixed crude co-culture, and 7 days incubation time. The experiments were undertaken under unadded and added sugar conditions to examine the effect of adding sugar on bioethanol production

Table 2

Plate count of microorganisms in mixed crude co-culture

\begin{tabular}{cccc} 
Co-culture & $\begin{array}{c}\text { Total bacteria } \\
\text { (CFU/g) }\end{array}$ & $\begin{array}{c}\text { Total yeast } \\
\text { (CFU/g) }\end{array}$ & $\begin{array}{c}\text { Total fungi } \\
\text { (CFU/g) }\end{array}$ \\
\hline Co-culture of T. reesei and S. cerevisiae & $<10 \pm 0.10$ & $<10 \pm 0.2$ & $2.67 \times 10 \pm^{8} 0.5 \times 10^{8}$ \\
\hline
\end{tabular}


Table 3

Ethanol production of orthogonal experiment for batch fermentation

\begin{tabular}{|c|c|c|c|c|}
\hline \multirow{2}{*}{ Experiment } & \multicolumn{3}{|c|}{ Factors } & \multirow{2}{*}{$\begin{array}{c}\text { Ethanol } \\
(\mathrm{g} / \mathrm{L})\end{array}$} \\
\hline & A & B & $\mathrm{C}$ & \\
\hline 1 & 5 & 2.5 & 3 & $7.03 \pm 1.16$ \\
\hline 2 & 10 & 5 & 3 & $7.25 \pm 1.21$ \\
\hline 3 & 15 & 7.5 & 3 & $10.23 \pm 1.22$ \\
\hline 4 & 20 & 10 & 3 & $7.57 \pm 0.02$ \\
\hline 5 & 25 & 12.5 & 3 & $7.77 \pm 0.58$ \\
\hline 6 & 30 & 15 & 3 & $7.93 \pm 0.02$ \\
\hline 7 & 35 & 17.5 & 3 & $12.22 \pm 4.31$ \\
\hline 8 & 5 & 17.5 & 4 & $10.70 \pm 0.14$ \\
\hline 9 & 10 & 2.5 & 4 & $6.96 \pm 0.22$ \\
\hline 10 & 15 & 5 & 4 & $9.30 \pm 1.30$ \\
\hline 11 & 20 & 7.5 & 4 & $5.45 \pm 0.18$ \\
\hline 12 & 25 & 10 & 4 & $8.52 \pm 0.08$ \\
\hline 13 & 30 & 12.5 & 4 & $6.53 \pm 0.45$ \\
\hline 14 & 35 & 15 & 4 & $9.48 \pm 0.03$ \\
\hline 15 & 5 & 15 & 5 & $11.11 \pm 2.12$ \\
\hline 16 & 10 & 17.5 & 5 & $10.91 \pm 2.49$ \\
\hline 17 & 15 & 2.5 & 5 & $7.00 \pm 2.53$ \\
\hline 18 & 20 & 5 & 5 & $6.88 \pm 0.41$ \\
\hline 19 & 25 & 7.5 & 5 & $7.95 \pm 0.60$ \\
\hline 20 & 30 & 10 & 5 & $8.17 \pm 0.14$ \\
\hline 21 & 35 & 12.5 & 5 & $10.71 \pm 0.08$ \\
\hline 22 & 5 & 12.5 & 6 & $7.89 \pm 0.35$ \\
\hline 23 & 10 & 15 & 6 & $10.63 \pm 0.31$ \\
\hline 24 & 15 & 17.5 & 6 & $12.16 \pm 0.02$ \\
\hline 25 & 20 & 2.5 & 6 & $7.28 \pm 0.58$ \\
\hline 26 & 25 & 5 & 6 & $6.55 \pm 0.14$ \\
\hline 27 & 30 & 7.5 & 6 & $8.70 \pm 0.60$ \\
\hline 28 & 35 & 10 & 6 & $8.78 \pm 0.44$ \\
\hline 29 & 5 & 10 & 7 & $11.63 \pm 0.09$ \\
\hline 30 & 10 & 12.5 & 7 & $16.17 \pm 0.14$ \\
\hline 31 & 15 & 15 & 7 & $16.90 \pm 0.66$ \\
\hline 32 & 20 & 17.5 & 7 & $9.50 \pm 0.00$ \\
\hline 33 & 25 & 2.5 & 7 & $5.51 \pm 0.13$ \\
\hline 34 & 30 & 5 & 7 & $8.56 \pm 0.14$ \\
\hline 35 & 35 & 7.5 & 7 & $12.24 \pm 0.64$ \\
\hline 36 & 5 & 7.5 & 8 & $11.08 \pm 0.25$ \\
\hline 37 & 10 & 10 & 8 & $12.06 \pm 0.00$ \\
\hline 38 & 15 & 12.5 & 8 & $14.62 \pm 0.16$ \\
\hline 39 & 20 & 15 & 8 & $11.11 \pm 0.02$ \\
\hline 40 & 25 & 17.5 & 8 & $9.45 \pm 1.87$ \\
\hline 41 & 30 & 2.5 & 8 & $7.16 \pm 0.06$ \\
\hline 42 & 35 & 5 & 8 & $9.38 \pm 0.48$ \\
\hline 43 & 5 & 5 & 9 & $7.48 \pm 0.49$ \\
\hline 44 & 10 & 7.5 & 9 & $10.13 \pm 0.12$ \\
\hline 45 & 15 & 10 & 9 & $10.40 \pm 0.52$ \\
\hline 46 & 20 & 12.5 & 9 & $9.27 \pm 0.53$ \\
\hline 47 & 25 & 15 & 9 & $11.07 \pm 0.85$ \\
\hline 48 & 30 & 17.5 & 9 & $10.27 \pm 0.15$ \\
\hline 49 & 35 & 2.5 & 9 & $7.50 \pm 0.59$ \\
\hline
\end{tabular}




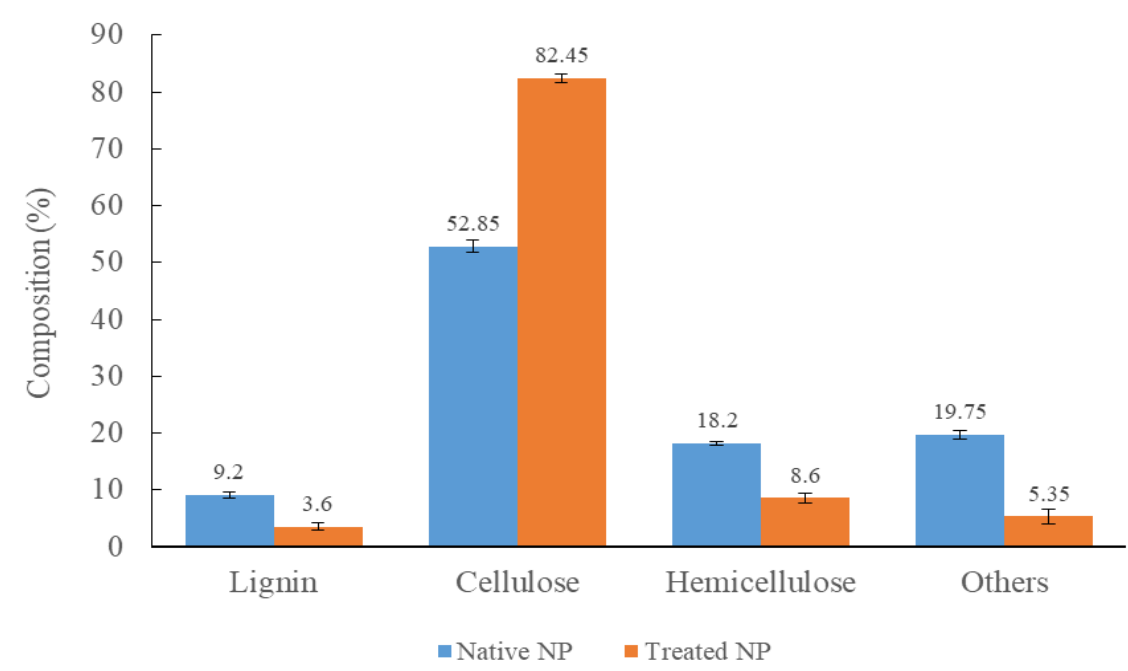

Fig 3 The chemical composition of Napier grass before and after $\mathrm{NaOH}$ pretreatment

In Figure 4, the initial reducing sugar (day 0) was as high as $33.0 \mathrm{~g}$ as a result of adding sugar. Reducing sugar continually increased as the co-culture fermentation converted cellulose into sugar and peaked to $46.7 \mathrm{~g}$ (day 4) and declined. It reversed on day 7 before declining and reversing again at termination (day 9). The phenomenon could be attributed to residual cellulose being converted into sugar. For unadded sugar condition during the initial incubation period, the co-culture fermentation converted cellulose into sugar for growth, causing reducing sugar to rise at an increasing rate at $4.96 \mathrm{~g}$ (day 0) and peaked at $12.7 \mathrm{~g}$ (day 4) and then was reduced steadily beyond day 4. The added sugar condition had a similar trend with unadded sugar except after day 6 , the swing may be due to the microbes' use of the added sugars, causing a slight increase in ethanol production. In Figure 5, the cell mass steadily grew during the first 4 days and peaked in day 5 and declined and reversed on day 8. Since larger proportions of converted sugar were consumed by the microbes, the bioethanol production increased slowly from days 0 to 4 and peaked at day $5(25.02 \mathrm{~g} / \mathrm{L})$ and steadily declined as the reducing sugar decreased. The cell mass minimally grew during the first 4 days of incubation and spiked in day 5 and decreased afterward, consistent with the pattern of reducing sugars. Figure 6 illustrates the bioethanol yields in the unadded and added sugar bioreactor tanks. The bioethanol production increased steadily from days 0 to, 4 peaked at day $5^{\text {th }}(33.24 \mathrm{~g} / \mathrm{L})$ and declined before reversing on day $8^{\text {th }}$. The maximum bioethanol yields were $25.02 \mathrm{~g} / \mathrm{L}$ (5-day incubation time) and $33.24 \mathrm{~g} / \mathrm{L}$ (5-day incubation time) under unadded and added sugar conditions. The higher bioethanol production under the added sugar condition was attributable to increased amounts of reducing sugar. The trend patterns of the ethanol yield of the unadded and added sugar states were similar and peaked at day 5 as well.

Table 4

Statistical analysis of orthogonal experiments for ethanol yields

\begin{tabular}{cccc}
\hline Level & A & Control parameters & C \\
\cline { 2 - 4 } & 66.92 & B & 60 \\
K1 & 74.11 & 48.44 & 56.94 \\
K3 & 80.61 & 55.4 & 62.73 \\
K4 & 57.06 & 65.78 & 61.99 \\
K5 & 56.82 & 67.13 & 80.51 \\
K6 & 57.32 & 72.96 & 74.86 \\
K7 & 70.31 & 78.23 & 66.12 \\
k1 & 22.31 & 75.21 & 20.00 \\
k3 & 24.70 & 16.15 & 18.98 \\
k4 & 26.87 & 18.47 & 20.91 \\
k5 & 19.02 & 21.93 & 20.66 \\
k6 & 18.94 & 22.38 & 26.84 \\
R & 19.11 & 24.32 & 24.95 \\
SD & 23.44 & 26.08 & 22.04 \\
Major-minor order B>A>C & 7.93 & 25.07 & 7.86 \\
The optimization scheme $\mathrm{B}_{6} \mathrm{~A}_{3} \mathrm{C}_{5}$ & & 9.93 & 2.83 \\
\hline
\end{tabular}


Citation: Mueansichai, T., Rangseesuriyachai, T., Thongchul, N., and Assabumrungrat, S. (2022) Lignocellulosic Bioethanol Production of Napier Grass Using Trichoderma reesei and Saccharomyces cerevisiae Co-Culture Fermentation. International Journal of Renewable Energy Development, 11(2), 423-433, doi: 10.14710/ijred.2022.43740

430 |

Table 5

Comparison between batch-scale ethanol yields from Napier grass under different fermentation schemes and co-culture fermentation

\begin{tabular}{|c|c|c|c|c|c|}
\hline \multirow[t]{2}{*}{ Microorganisms } & \multirow[t]{2}{*}{ Pretreatment } & \multirow[t]{2}{*}{ Process } & \multicolumn{2}{|c|}{ Maximum ethanol yield } & \multirow[t]{2}{*}{ References } \\
\hline & & & $(g / L)$ & (\%) & \\
\hline $\begin{array}{l}\text { Saccharomyces cerevisiae, } \\
\text { Accellerase } 1500\end{array}$ & Alkaline $(\mathrm{NaOH})$ & SSF & 27.7 & 92 & Cardona et al., (2016) \\
\hline $\begin{array}{l}\text { Aspergillus niger, Saccharomyces } \\
\text { cerevisiae }\end{array}$ & Alkaline $(\mathrm{NaOH})$ & SSF & 23.4 & 78 & Aiyejagbara et al., (2016) \\
\hline $\begin{array}{l}\text { Aspergillus niger, Trichoderma } \\
\text { reesei, Zymomonas mobilis }\end{array}$ & None & SSCF & 15 & 50 & Liu et al., (2017) \\
\hline $\begin{array}{l}\text { Saccharomyces cerevisiae, } \beta \text { - } \\
\text { glucosidase, PEG } 6000\end{array}$ & $\begin{array}{l}\text { Dilute acid }\left(\mathrm{H}_{2} \mathrm{SO}_{4}\right) \\
\text { and Alkaline } \\
(\mathrm{NaOH})\end{array}$ & SSF & 24 & 81 & Camesasca et al., (2015) \\
\hline $\begin{array}{l}\text { Penicillium echinulatum, } \\
\text { Saccharomyces cerevisiae }\end{array}$ & Steam explosion & $\mathrm{SHF}$ & 4.42 & 17 & Scholl et al., (2015) \\
\hline $\begin{array}{l}\text { Trichoderma reesei, Saccharomyces } \\
\text { cerevisiae }\end{array}$ & Alkaline $(\mathrm{NaOH})$ & SSF & $25.02 \pm 1.3$ & 83 & This study \\
\hline
\end{tabular}

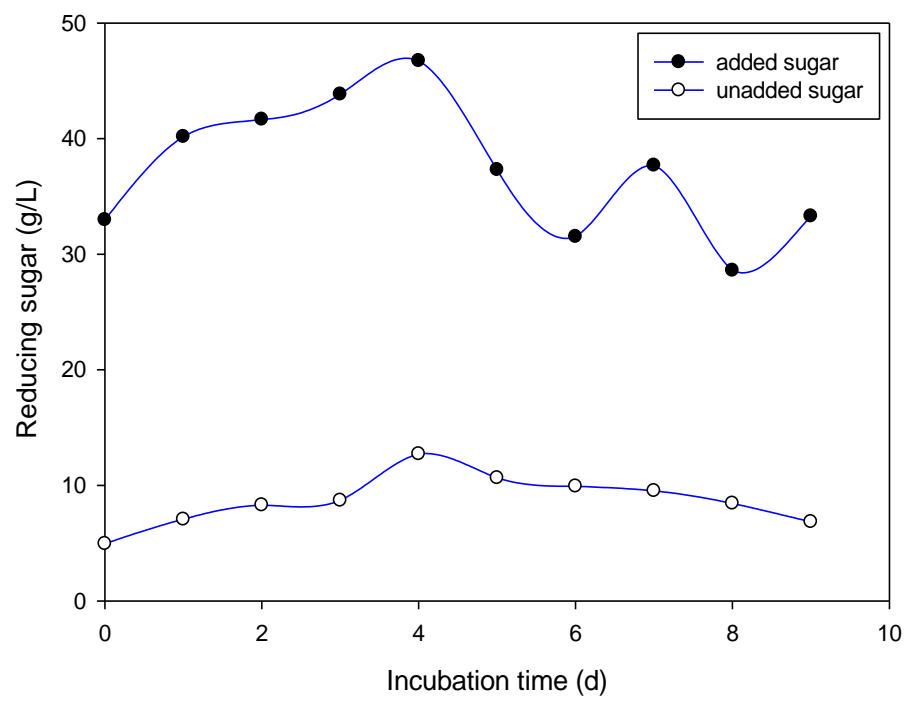

Fig 4 Reducing sugar in batch-scale fermentation of unadded and added sugar conditions

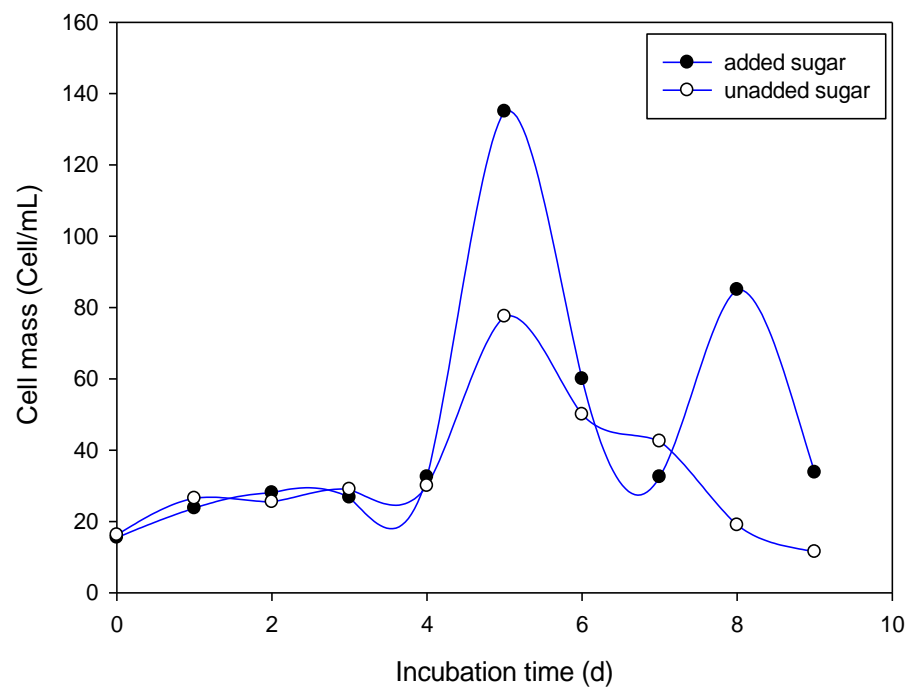

Fig 5 Cell mass in batch-scale fermentation of unadded and added sugar conditions 


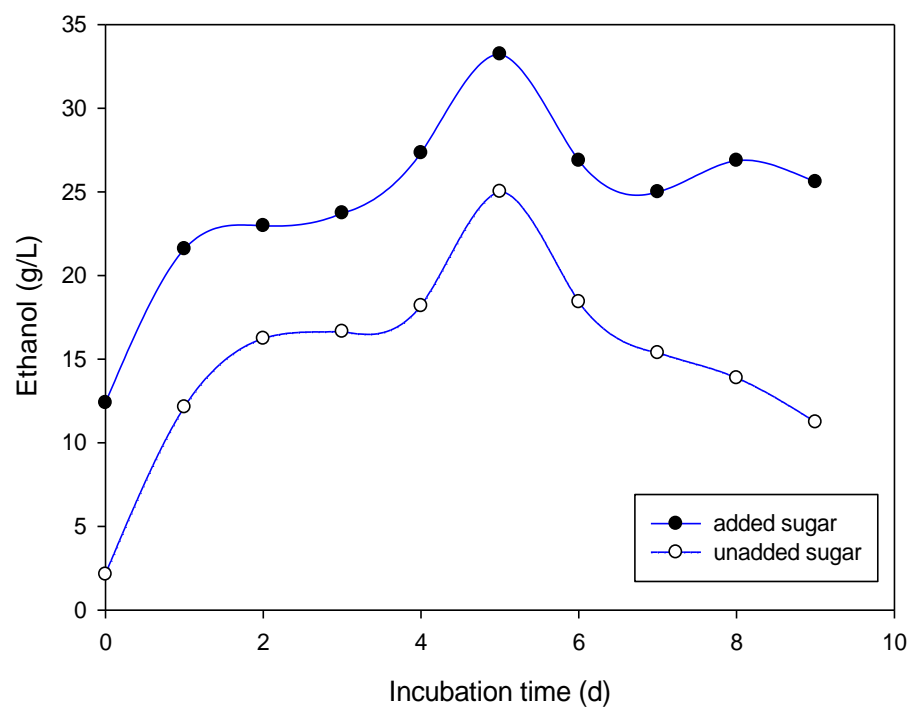

Fig 6 Ethanol yields in batch-scale fermentation of unadded and added sugar conditions

From the orthogonal experiment in Table 4, the effect of each independent variable on the bioethanol yield is based on the biggest average value of $\mathrm{k}_{\mathrm{i}}$. For Napier grass, when the amount was increased, the bioethanol yield was increased. The highest value of the bioethanol yield is at $\mathrm{k}_{3}(15 \mathrm{~g})$. Then, the yield decreased when the amount of Napier grass was further increased. The second variable is the mixed crude co-culture. When the amount of mixed crude co-culture was increased, the bioethanol yield was also increased. The highest value of the bioethanol yield is at $\mathrm{k}_{6}(15 \mathrm{~g})$. The last variable is the incubation time. The change of the bioethanol yield is very small in the first 6 days but it increased to the highest value at $\mathrm{k}_{5}$ (day 7 ).

By comparison, reducing sugars under the added sugar condition (33.0 g) was nearly seven times higher than under the unadded sugar condition (4.96 g). However, the maximum bioethanol yield under the added sugar condition $(33.24 \pm 1.8 \mathrm{~g} / \mathrm{L})$ was slightly greater than that under the unadded sugar condition $(25.02 \pm 0.5 \mathrm{~g} / \mathrm{L})$ (merely $8.22 \mathrm{~g} / \mathrm{L}$ ) . The ethanol yield of the two conditions was not significantly different ( $p$-value $<0.05)$. This result indicated that added sugar minimally enhanced bioethanol production. The small increase in the bioethanol yield, despite increased sugar content, could be attributed to considerably smaller proportions of yeast $(<10 \mathrm{CFU} / \mathrm{g})$ to fungi $\left(2.67 \times 10^{8} \mathrm{CFU} / \mathrm{g}\right)$ in the co-culture fermentation. Fungi is essential for the conversion of sugar into bioethanol.

Table 5 compares the bioethanol production from Napier grass using different fermentation technologies and co-culture fermentation. In this study, the bioethanol yield under the optimal SSF condition (15 g Napier grass, $15 \mathrm{~g}$ mixed crude co-culture, and 5 days incubation) was $25.02 \mathrm{~g} / \mathrm{L}$, consistent with Cardona et al., (2016), who used S. cerevisiae and Accellerase 1500. Nevertheless, given the relatively lower costs and greater durability, T. reesei and $S$. cerevisiae co-culture fermentation is more attractive than that of S. cerevisiae and Accellerase 1500 (Cardona et al., 2016).
This work focuses on second-generation feedstock for bioethanol production, which has the limitation of highcost involvements and energy consumption. The results of this work used the pretreatment method from previous study and scale up only two sizes of the reactors. The authors suggest that a new method of DOE such as the Box-Behnken design based on the response surface methodology should be used in further studies. It combines both mathematical and statistical techniques that are useful in modeling and problem analysis and is effective in reducing the sample count in experiments. Moreover, the economic feasibility should be considered for up-scaling to industrial-scale research in the future.

\section{.4. Conclusion}

This research investigated the use of $T$. reesei and $S$. cerevisiae co-culture fermentation in the production of bioethanol from Napier grass using SSF technology. Napier grass was pretreated with $3 \%(w / w) ~ N a O H$, and an orthogonal experimental design was utilized to optimize the Napier grass content, mixed crude co-culture loading, and incubation time for maximum bioethanol production. The pretreatment increased the cellulose content from $52.85 \%$ to $82 \%$. The optimal fermentation condition that maximized the bioethanol yield was 15 g Napier grass, 15 $\mathrm{g}$ mixed crude co-culture, and 7-day incubation time that gave the maximum bioethanol yield of the laboratory-scale experiments to $16.90 \mathrm{~g} / \mathrm{L}$. To scale up, the fermentation was done with 20 -fold Napier grass content, mixed crude enzyme, and working volume with and without added sugar. The maximum bioethanol yields of scale up experiments were found at 25.02 and $33.24 \mathrm{~g} / \mathrm{L}$ for unadded and added sugar, respectively. The results revealed that $T$. reesei and $S$. cerevisiae co-culture fermentation is suitable for bioethanol production of Napier grass. 


\section{Acknowledgments}

The authors would like to extend deep gratitude to the Faculty of Engineering, Rajamangala University of Technology Thanyaburi (RMUTT), for the research facility. Sincere appreciation also goes to Mr. Erfarn Abdullah, Mr. Kengkad Chankawikun, and Miss Rungtawan Sriwisat, for technical assistance. The authors would like to thank Enago (www.enago.com) for the English language review.

\section{References}

Adekunle, A., Orsat, V. \& Raghavan, V. (2016). Lignocellulosic bioethanol: A review and design conceptualization study of production from cassava peels. Renewable and Sustainable Energy Reviews 64, 518-530; doi: 10.1016/j.rser.2016.06.064

Aiyejagbara, M. O., Aderemi, B.O., Ameh, A.O., Ishidi, E., Aiyejagbara, E.F., Ibeneme, U. \& Olakunle, M.S. (2016). Production of Bioethanol from Elephant Grass (Pennisetum purpureum) Stem. International Journal of Innovative Mathematics, Statistics \& Energy Policies 4(1), 1-9; doi: 10.4314/njb.v32i1.1

Akhtar, N., Goyal, D., \& Goyal A. (2017). Characterization of microwave-alkali-acid pre-treated rice straw for optimization of ethanol production via simultaneous saccharification and fermentation (SSF). Energy Conversion and Management, 1(141), 133-44; doi: 10.1016/j.enconman.2016.06.081

Alfani, F., Gallifuoco, A., Saporosi, A., Spera, A., \& Cantarella, M. (2000). Comparison of SHF and SSF processes for the bioconversion of steam-exploded wheat straw. Journal of Industrial Microbiology and Biotechnology, 25(4), 184-192; doi: $10.1038 /$ sj.jim.7000054

Ariyanti, D., and Hadiyanto, H (2013). Ethanol production from whey by kluyveromyces marxianus in batch fermentation system: Kinetics parameters estimation. Bulletin of Chemical Reaction Engineering and Catalysis, 7(3),179-184; doi: 10.9767/bcrec.7.3.4044.179-184

Azhar, S.H.M., Abdulla, R., Jambo, S.A., Marbawi, H., Gansau, J.A., Faik, A.A.M. \& Rodrigues, K.F. (2017). Yeasts in sustainable bioethanol production: A review. Biochemistry and Biophysics Reports 10, 52-61; doi: 10.1016/j.bbrep.2017.03.003

Banka, A., Komolwanich, T. \& Wongkasemjit, S. (2015). Potential Thai grasses for bioethanol production. Cellulose 22(1), 9-29; doi.org/10.1007/s10570-014-0501-2

Burman, N. W., Sheridan, C. M., \& Harding, K. G. (2020), Feasibility assessment of the production of bioethanol from lignocellulosic biomass pretreated with acid mine drainage (AMD). Renewable Energy, 157, 1148-1155; doi: 10.1016/j.renene.2020.05.086

Camesasca, L., Ramírez, M.B., Guigou, M., Ferrari, M.D. \& Lareo, C. (2015). Evaluation of dilute acid and alkaline pretreatments, enzymatic hydrolysis and fermentation of napiergrass for fuel ethanol production. Biomass and Bioenergy 74, 193-201; doi: 10.1016/j.biombioe.2015.01.017

Cardona, E., Rio, J., Peña, J., Peñuela, M. \& Rio, L. (2016). King Grass: A very promising material for the production of second generation ethanol in tropical countries. Biomass and Bioenergy 95, 206-213; doi: 10.1016/j.biombioe.2016.10.008

Chaturvedi, V., \& Verma, P. (2013). An overview of key pretreatment processes employed for bioconversion of lignocellulosic biomass into biofuels and value added products. 3 Biotech, 3(5), 415-431. doi: 10.1007/s13205-0130167-8

Chen, H., Liu, J., Chang, X., Chen, D., Xue, Y., Liu, P., Lin, H. \& Han, S. (2017). A review on the pretreatment of lignocellulose for high-value chemicals. Fuel Processing Technology 160, 196-206; doi: 10.1016/j.fuproc.2016.12.00

Cotana, F., Cavalaglio, G., Gelosia, M., Coccia, V., Petrozzi, A., Ingles, D., \& Pompili, E. (2015). A comparison between SHF and SSSF processes from cardoon for ethanol production. Industrial Crops and Products, 69, 424-432; doi: 10.1016/j.indcrop.2015.02.064

Dahnum, D., Tasum, S.O., Triwahyuni, E., Nurdin, M. \& Abimanyu, H. (2015). Comparison of SHF and SSF Processes Using Enzyme and Dry Yeast for Optimization of Bioethanol Production from Empty Fruit Bunch. Energy Procedia 68, 107-116; doi: 10.1016/j.egypro.2015.03.238

Eliana, C., Jorge, R., Juan, P. \& Luis, R. (2014). Effects of the pretreatment method on enzymatic hydrolysis and ethanol fermentability of the cellulosic fraction from elephant grass. Fuel 118, 41-47; doi: 10.1016/j.fuel.2013.10.055

Ghose, T. K. (1987) Measurement of cellulase activities. Pure and applied Chemistry, 59(2), 257-68; doi: 10.1351/pac198759020257

Gusakov, A.V. (2011). Alternatives to Trichoderma reesei in biofuel production. Trends in Biotechnology 29(9), 419-425; doi: 10.1016/j.tibtech.2011.04.004

He, C.R., Kuo, Y.Y. \& Li, S.Y. (2017). Lignocellulosic butanol production from Napier grass using semi-simultaneous saccharification fermentation. Bioresource Technology 231, 101-108; doi: 10.1016/j.biortech.2017.01.039

Kamarullah, S.H., Mydin, M.M., Omar, W.S.A.W., Harith, S.S., Noor, B.H.M., Alias, N.Z.A., Manap, S. \& Mohamad, R. (2015). Surface Morphology and Chemical Composition of Napier Grass Fibers. Malaysian Journal of Analytical Sciences 19(4), 889-895.

Kataria, R. \& Ghosh, S. (2011). Saccharification of Kans grass using enzyme mixture from Trichoderma reesei for bioethanol production. Bioresource Technology 102(21), 9970-9975; doi: 10.1016/j.biortech.2011.08.023

Kim, J.S., Lee, Y.Y. \& Kim, T.H. (2016). A review on alkaline pretreatment technology for bioconversion of lignocellulosic biomass. Bioresource Technology 199, 42-48; doi: 10.1016/j.biortech.2015.08.085

Kommula, V.P., Reddy, K.O., Shukla, M., Marwala, T. \& Rajulu, A.V. (2013). Physico-chemical, Tensile, and Thermal Characterization of Napier Grass (Native African) Fiber Strands. International Journal of Polymer Analysis and Characterization, 18, 303-314

Kongkeitkajorn, M.B., Sae-Kuay, C. \& Reungsang, A. (2020). Evaluation of Napier Grass for Bioethanol Production through a Fermentation Process. Processes, 8(5), 567-685; doi: $10.3390 / p r 8050567$

Kusmiyati, Hadiyanto, H. \& Kusumadewi, I. (2016). Bioethanol Production from Iles-Iles (Amorphopallus campanulatus) Flour by Fermentation using Zymomonas mobilis. International Journal of Renewable Energy Development, 5(1), 9-14; doi: 10.14710/ijred.5.1.9-14

Liu, Y.K., Chen, W.C., Huang, Y.C., Chang, Y.K., Chu, I.M., Tsai, S.L. \& Wei, H.W. (2017). Production of bioethanol from Napier grass via simultaneous saccharification and cofermentation in a modified bioreactor. Journal of Bioscience and Bioengineering 124(2): 184-188; doi: 10.1016/j.jbiosc.2017.02.018

Loaces, I., Schein, S. \& Noya, F. (2017). Ethanol production by Escherichia coli from Arundo donax biomass under SSF, SHF or CBP process configurations and in situ production of a multifunctional glucanase and xylanase. Bioresource Technology 224: 307-313; doi: 10.1016/j.biortech.2016.10.075

Mafuleka, S. \& Kana, E.B.G. (2015). Modelling and optimization of xylose and glucose production from napier grass using hybrid pre-treatment techniques. Biomass and Bioenergy 77, 200-208; doi: 10.1016/j.biombioe.2015.03.031

Menegol, D., Fontana, R.C., Dillon, A.J.P. \& Camassola, M. (2016). Second-generation ethanol production from elephant grass at high total solids. Bioresource Technology 211, 280290; doi: 10.1016/j.biortech.2016.03.098

Miller, G.L. (1959). Use of dinitrosalicylic acid and reagent for determination of reducing sugar. Analytical Chemistry 31, 426-427; doi: 10.1021/ac60147a030

Mohammad, I., Abakr, Y., Kabir, F., Yusuf, S., Alshareef, I., \& Chin, S. (2015). Pyrolysis of Napier grass in a fixed bed 
reactor: effect of operating conditions on product yields and characteristics. BioResources, 10(4), 6457-6478. doi: 10.15376/biores.10.4.6457-6478

Rahayu, F., Kawai, Y., Iwasaki, Y., Yoshida, K., Kita, A., Tajima, T., Kato, J., Murakami, K., Hoshino, T. \& Nakashimada, Y. (2017). Thermophilic ethanol fermentation from lignocellulose hydrolysate by genetically engineered Moorella thermoacetica. Bioresource Technology 245, 1393-1399; doi: 10.1016/j.biortech.2017.05.146

Reddy, K.O., Maheswari, C,U., Shukla, M. \& Muzenda, E. (2014). Preparation, Chemical composition, Characterization, and Properties of Napier Grass Paper Sheets. Separation Science and Technology, 49, 1527-1534; doi: 10.1080/01496395.2014.893358

Restiawaty, E., Gani, K.P., Dewi, A., Arina, L.A., Kurniawati, K.I., Wibisono, Y. \& Akhmaloka (2020). Bioethanol Production from Sugarcane Bagasse Using Neurospora intermedia in an Airlift Bioreactor. International Journal of Renewable Energy Development, 9(2), 247-253; doi: 10.14710/ijred.9.2.247-253

Pensri, B., Aggarangsi, P., Chaiyaso, T. \& Chandet, N. (2016). Potential of Fermentable Sugar Production from Napier cv. Pakchong1 Grass Residue as a Substrate to Produce Bioethanol. Energy Procedia 89, 428-436; doi: 10.1016/j.egypro.2016.06.287

Prajankate, P. \& Siwarasak, P. (2011). Co-culture of Trichoderma reesei RT-P1 with Saccharomyces cerevisiae RT-P2: Morphological Studies. Journal of the Microscopy Society of Thailand 4(2), 75-78.

Sanford, G., Oates, L.G., Roley, S., Duncan, D.S., Jackson, R.D., Robertson, G.P. \& Thelen, K.D. (2017). Biomass Production a Stronger Driver of Cellulosic Ethanol Yield than Biomass Quality. Agronomy Journal 109(5), 1-12; doi: 10.2134/agronj2016.08.0454

Sawasdee, V. \& Pisutpaisal, N. (2014). Feasibility of Biogas Production from Napier Grass. Energy Procedia 61: 12291233; doi: 10.1016/j.egypro.2014.11.1064

Scholl, A.L., Menegol, D., Piitarelo, A.P., Fontana, R.C., Filho, A.Z., Ramos, L.P., Dillon, A.J.P. \& Camassola, M. (2015). Ethanol production from sugars obtained during enzymatic hydrolysis of elephant grass (Pennisetum purpureum, Schum.) pretreated by steam explosion. Bioresource Technology 192, 228-237; doi: 10.1016/j.biortech.2015.05.065

Sharma, P., Sharma, N. \& Sharma, N. (2019) Scale up and optimization of process parameters for high gravity ethanol fermentation from a fresh water algae Rhizoclonium sp. of Trans Himalayas using Taguchi orthogonal array design, kinetics and modeling. Journal of Pharmacognosy and Phytochemistry, 8(1), 1386-98.

Sharma, B., Larroche, C., \& Dussap, C. G. (2020). Comprehensive assessment of $2 \mathrm{G}$ bioethanol production. Bioresource Technology 313, 123630; doi: 10.1016/j.biortech.2020.123630.
Siwarasak, P., Pajantagate, P. \& Prasertlertrat, K. (2012). Use of Trichoderma reesei RT-P1 crude enzyme powder for ethanol fermentation of sweet sorghum fresh stalks. Bioresource Technology 107, 200-204; doi: 10.1016/j.biortech.2011.12.009

Sudiyani, Y., Triwahyuni, E., Muryanto, Burhani, D., Waluyo, J., Sulaswaty, A. \& Abimanyu, H. (2016). Alkaline Pretreatment of Sweet Sorghum Bagasse for Bioethanol Production. International Journal of Renewable Energy Development, 5(2), 113-118; doi: 10.14710/ijred.5.2.113-118

Taherzadeh, M.J. \& Karimi, K. (2008). Pretreatment of Lignocellulosic Wastes to Improve Ethanol and Biogas Production: A Review. International Journal of Molecular Sciences 9, 1621-1651; doi: 10.3390/ijms9091621

Tran, D.T., I, Y.P. \& Lin, C.W. (2013). Developing co-culture system of dominant cellulolytic Bacillus sp. THLA0409 and dominant ethanolic Klebsiella oxytoca THLC0409 for enhancing ethanol production from lignocellulosic materials. Journal of the Taiwan Institute of Chemical Engineers 44(5), 762-769; doi: 10.1016/j.jtice.2013.01.028

Triantafyllidis, K., Lappas, A. \& Stöcker, M. (2013). The Role of Catalysis for the Sustainable Production of Bio-fuels and Biochemicals, 1st edn. Elsevier, Amsterdam.

Tsai, M.H., Lee, W.C., Kuan, W.C., Sirisansaneeyakul, S. \& Savarajara, A. (2018). Evaluation of different pretreatments of Napier grass for enzymatic saccharification and ethanol production. Energy Science \& Engineering, 6, 683-692; doi: 10.1002/ese 3.243

Williams, M.B. \& Reese, D. (1950). Colorimetric determination of ethyl alcohol. Analytical Chemistry 22, 1463-1582; doi: 10.1021/ac60048a025

Wingren, A., Galbe, M., \& Zacchi, G. (2003). Techno-economic evaluation of producing ethanol from softwood: Comparison of SSF and SHF and identification of bottlenecks. Biotechnology progress, 19(4), 1109-1117; doi: 10.1021/bp0340180

Wongwatanapaiboon, J., Kangvansaichol, K., Burapatana, V., Inochanon, R., Winayanuwattikun, P., Yongvanich, T. \& Chulalaksananukul, W. (2012). The Potential of Cellulosic Ethanol Production from Grasses in Thailand. Journal of Biomedicine and Biotechnology 2012, 1-10; doi: 10.1155/2012/303748

Xu, Q., Himmel, M.E. \& Singh, A. (2015). Chapter 11 - Production of Ethanol from Engineered Trichoderma reesei. Direct Microbial Conversion of Biomass to Advanced Biofuels. 197208; doi: 10.1016/B978-0-444-59592-8.00011-7

Yasuda, M., Nagai, H., Takeo, K., Ishii, Y. \& Ohta, K. (2014). Bioethanol production through simultaneous saccharification and co-fermentation (SSCF) of a low-moisture anhydrous ammonia (LMAA)-pretreated napiegrass (Pennisetum purpureum Schumach). Springerplus 3(333), 1-8; doi: 10.1186/2193-1801-3-333. 